\title{
Epigeic ants (Hymenoptera: Formicidae) in vineyards and grassland areas in the Campanha region, state of Rio Grande do Sul, Brazil
}

\author{
João L. O. Rosado ${ }^{1 *}$, Michel G. de Gonçalves ${ }^{1}$, William Dröse ${ }^{1}$, Eduardo J. E. e Silva ${ }^{1}$, Rodrigo F. Krüger ${ }^{2}$, \\ Rodrigo M. Feitosa ${ }^{3}$ and Alci E. Loeck ${ }^{1}$ \\ 1 Universidade Federal de Pelotas, Faculdade de Agronomia Eliseu Maciel, Departamento de Fitossanidade. Campus Universitário. Caixa Postal \\ 354. CEP 96010-900. Pelotas, RS, Brazil. \\ 2 Universidade Federal de Pelotas, Departamento de Microbiologia e Parasitologia. Campus Universitário. Caixa Postal 354. CEP 96010-900. \\ Pelotas, RS, Brazil. \\ 3 Universidade de São Paulo, Museu de Zoologia, CEP 04263-000. São Paulo, SP, Brazil. \\ * Corresponding author. E-mail: jhotabio@gmail.com
}

\begin{abstract}
In order to characterize the epigeic myrmecofauna in fields and vineyards in the physiographic region of Campanha, located in the Pampa biome, state of Rio Grande do Sul, inventories were conducted on three farms. On each farm, samples were collected in three environments: the rows in the vineyards, the spaces between rows in the vineyards, and the adjacent areas, with vegetation similar to that which preceded the establishment of crops. In each environment, 20 points were sampled using pitfall traps. We collected 72 species distributed among 24 genera and seven subfamilies. The study provides the first inventory of the ant fauna in the region, contributing with new records for the state of Rio Grande do Sul and for Brazil. It is hoped that this inventory will stimulate further studies on the biodiversity of this biome that is still poorly known.
\end{abstract}

\section{INTRODUCTION}

The growing concern over environmental issues, especially the impact of human activities, with the alteration of habitats and the consequent reduction in biodiversity, has mobilized the scientific community to conduct studies that increase knowledge about the biological diversity of various ecosystems (Queiroz et al. 2006). Species inventories are very useful to support subsequent, more detailed studies on the structure and functioning of ecological communities (Alonso and Agosti 2000). These inventories can provide essential information about the distribution of individuals, biological properties and the presence of rare or ecologically important species, whether introduced or endemic (Wilson 1997). These studies may also lead to the establishment of techniques for the sustainable exploitation of biotic and abiotic resources of the studied environments (Prado 1980).

Ants are one of the most studied groups in the world (Lach et al. 2010). Currently there are 12,643 described species (Agosti and Johnson 2012), although it is estimated that there may be around 22,000 species (Agosti and Johnson 2003). Due to their ecological characteristics, ants are considered one of the groups of invertebrates with the most important role in terrestrial ecosystems (Majer 1983), acting in several ecological functions, such as improvement of the physical-chemical properties of the soil due to increased fertility (transport of organic matter) and of the soil porosity (construction of subterranean galleries and chambers in the nests), population control of other invertebrates due to the predatory habit of many species, as well as contributing to dispersal and pollination processes (Hölldobler and Wilson 1990; Folgarait 1998;
Silva and Brandão 1999; Queiroz et al. 2006).

In Brazil, inventories of the myrmecofauna have been carried out at various locations, whether natural or subjected to human disturbance, and a few biomes, such as the Cerrado (Marinho et al. 2002; Andrade et al. 2007; Soares et al. 2010) and the Atlantic Forest (Dias et al. 2008; Rosumek et al. 2008; Gomes et al. 2010) have been studied in more detail. On the other hand, for the Pampa biome, the knowledge of its ant fauna is still incipient.

The Pampa biome, which covers an area of 176,496 $\mathrm{km}^{2}$, occupies $63 \%$ of the territory of the state of Rio Grande do Sul in southern Brazil, representing only $2.07 \%$ of the Brazilian biomes (IBGE 2004). However, the Pampa is a complex biome composed of several vegetation formations, among which the grasslands dominated by C3 grasses are the most representative, with inclusions of forests on the banks of streams and slopes of hills. The structure of the vegetation is very diverse, in response to the diversity and range of factors such as climate and soil, as well as the management to which this vegetation is submitted (Pillar et al. 2009).

Like other Brazilian biomes, the Pampa biome has been suffering from a reduction of its native areas due to agricultural expansion (Overbeck et al. 2009), often forming a mosaic of agroecosystem landscapes and areas of native vegetation in various stages of conservation, shapes and sizes (Dias et al. 2008).

Among agroecosystems found in Rio Grande do Sul, the cultivation of vines, has social and economic importance to the state. That said, as with other conventional agricultural systems, it causes simplification of the landscape because of the removal of native vegetation, and the need for 
pesticides to protect against etiological agents is also a concern. These activities may lead to a loss of biodiversity and ecosystem imbalance (Garcia 2001). However, the conservation of remnant native vegetation adjacent to cultivated areas can serve as a source of migrants, such pollinators and dispersers, for the maintenance of biodiversity in general, besides providing natural enemies for the pests that may damage the crops. Thus, the occupation of the landscape by agroecosystems does not necessarily transform it into a completely inhospitable environment to all native species (Dias et al. 2008).

In areas such as the Campanha region, especially with cultivation of vines, there is a lack of information about the behaviour of ant assemblages as they relate to the implementation of these ecosystem matrices indicating, initially, the need to carry out inventories. Thus, the purpose of this study was to characterize the epigeic ant fauna in areas with cultivation of vines and adjacent native sites in three farms located in the physiographic Campanha region, inserted in the Pampa biome, in the state of Rio Grande do Sul. This study, besides contributing to the knowledge of the species present in this region, constitutes a significant database that can aid in making future management and conservation plans for these habitats.

\section{MATERIALS AND Methods}

\section{Study Area}

The study was conducted in three areas with cultivation of Vitis vinifera Linnaeus (1758) cv Cabernet Sauvignon with a mean age of seven years old, and three areas of native grassland adjacent to these. The areas are located in the Pampa biome, specifically in the physiographic region of Campanha in the municipalities of Bagé (Fazenda Peruzzo Granja Santa Tecla - 31ำ15'S 540ㅗ'W and Fazenda Malafai - Granja São Martim - 31ำ16’S 540ㅜ' $)$ and Candiota

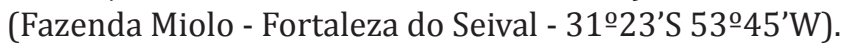

The Campanha physiographic region is characterized by a gently undulating topography which is rarely interrupted by plateaus (Marchiori 2004). The dominant vegetation is subtropical grasslands, sometimes forming "vassourais" (shrub lands).

Along the rivers there are shrub-like gallery forests, broadleaf forests and, sporadically, "capões" (wood islands) (Fortes 1959). According to the IBGE (2004) vegetation maps, the region of Campanha is classified as type grassywoody steppe savanna. According to the classification of Köppen, the climate is subtropical Cfa (Köppen 1936; Peel et al. 2007), with four well-defined annual seasons, characterized by average annual temperatures below $21^{\circ} \mathrm{C}$, with occurrence of hot summers and frosts during the winter.

\section{Data Collection}

Data collection was carried out over two years, with a sampling effort of one collection per season (spring 2009 to winter 2011). The three farms were sampled in each collection.

These farms were considered replicas of the sampled environments. In each farm, 60 collection points were marked, 20 in the grassland areas and 40 in the vineyard areas. In the vineyard areas, 20 points were marked in the rows and 20 in the spaces between rows. The rows and spaces were considered different environments and, therefore, different treatments. This distinction was established because agrotoxics were applied in the rows, whereas the spaces between rows were simply mowed.

In the grassland areas the sampling points were divided equally into two transects (ten points/transect), each $180 \mathrm{~m}$ long. In the vineyards the collection points along the rows and spaces were installed in an interwoven pattern so that, on the Peruzzo and the Miolo farms, the points were distributed along seven transects (six points/ transect), each $120 \mathrm{~m}$ long. On the Fazenda Malafai the collection points were distributed along five transects (eight points/transect), each $140 \mathrm{~m}$ long. In the absence of a predetermined specific protocol, we respected a minimum distance of $20 \mathrm{~m}$ from the boundaries of each area to avoid the edge effect. To ensure the independence of the samples a distance of $20 \mathrm{~m}$ was maintained between one another.

Pitfall traps were used, consisting of plastic $200 \mathrm{~mL}$ bottles, buried up to their upper edge, containing a solution of water, glycerine and salt at $5 \%$. The pitfall traps were kept in the field for 72 hours, after which they were removed, properly labelled and transported to the Myrmecology Laboratory of the Plant Protection Department of the Federal University of Pelotas (UFPEL), where the material was sorted and stored in vials containing ethanol at 70\%.

The ants were identified to genus level with the use of a dichotomous key (Palacio and Fernández 2003). When possible the identification was made to the species level, otherwise the groups were treated as morpho-species.

The determination of the species was made through the use of keys of Gonçalves (1961), Kempf (1965), Watkins (1976), Wilson (2003), Longino and Fernandez (2007) and Wild (2007b) and by comparison with the material available in the collection of the Museum of Zoology of São Paulo University(MZSP). The taxonomic classification follows Bolton et al. (2006) and Lapolla et al. (2010). Specimens of all species collected were deposited in the collections of MZSP and in the Entomological Museum Ceslau Biezanko (MECB) of UFPEL.

\section{RESULTS AND DISCUSSION}

Our inventory sampled 72 ant species, which were distributed amongst 24 genera and seven subfamilies. The number of ants identified until species levels corresponded to $55 \%$ of all ants sampled. Myrmicinae was the most speciose subfamily with 41 species, followed by Formicinae (11 species), Ponerinae (10 species), Dolichoderinae (six species), Ectatomminae (two species), Ecitoninae and Pseudomyrmecinae (one species each). The five genera with highest number of species were: Pheidole Westwood, 1839 (12 species); Solenopsis Westwood, 1840 (11 species); Acromyrmex Mayr, 1865 and Hypoponera Santschi, 1938 (seven species each); and Camponotus Mayr, 1861 (five species) (Table 1).

The predominance of the subfamilies Myrmicinae, Formicinae and Ponerinae, and the genera cited above was expected since these are common and abundant groups, especially in the Neotropics. This is corroborated by most inventories carried out in Brazil, regardless of the methodology and the study site, such as those performed by Marinho et al. (2002), Côrrea et al. (2006) and Andrade et al. (2007). 
Among the predominant genera, Pheidole is considered a hyperdiverse generalist ant, widely distributed and known for its mass recruitment system, which allows it to dominate food resources efficiently and to exclude competitors (Fowler 1993; Wilson 2003). The species of the genus Solenopsis are typically generalists with regard to their habitat and diet (Gonçalves and Nunes 1984), and are distinguished for their aggressiveness in the use of soil and litter, being found frequently both in native environments and in agroecosystems (Delabie and Fowler 1995). Ants of this group are able to withstand long periods of food scarcity, and also have effective strategies for mass recruitment (Fowler et al. 1991).

Leaf-cutting ants of the genus Acromyrmex are endemic to the Neotropical region and part of the Neartic region, being widely distributed throughout Brazil, causing considerable damage to agriculture by cutting plant material from most cultivated plants (Loeck et al. 2003) for the cultivation of a symbiotic fungus on which they feed. Of the eight species recorded for the region of Campanha by Loeck and Grützmacher (2001), only the species Acromyrmex laticeps Emery, 1905 was not recorded in the present inventory.

The species of Hypoponera are solitary predators of relatively small size, not very agile, foraging preferentially in hipogeic strata. Their colonies are small, located on the ground or under rocks and logs (Silvestre et al. 2003). The genus Camponotus has wide distribution, consisting of omnivorous species of arboreal and terrestrial habits, classified as dominant organisms, according to the Cerrado guilds, described by Delabie et al. (2000) and Silvestre et al. (2003). This genus has many species with high capacity to invade new environments, due to both their adaptability and diet flexibility (Ramos et al. 2003).

The species Brachymyrmex patagonicus Mayr, 1868; Brachymyrmex sp.4; Crematogaster quadriformis Roger, 1863; Dorymyrmex pyramicus (Roger, 1863); Pheidole aberrans Mayr, 1868; P. humeridens Wilson, 2003; P. nubila Emery, 1906; P. obtusopilosa Mayr, 1887; P. spininods Mayr, 1887; Pheidole sp.3; Pheidole sp.4; Solenopsis sp.1; and Wasmannia auropunctata (Roger, 1863) were the only ones that occurred on all the farms and environments sampled. All the mentioned species belong to highly generalist genera that are widely distributed in the Neotropics.

In this inventory, the species Crematogaster bruchi Forel, 1912 was recorded for the first time in Brazil. This species has been reported in Argentina (Kempf 1972; Vittar 2008; Vittar and Cuezzo 2008) and Paraguay (Wild 2007a). The genus Crematogaster Lundi, 1831 brings together a large number of generalist and omnivorous species, many of which are dominant arboreal species, although they also occur in the soil and leaf litter (Delabie et al. 2000).

The presence of Camponotus blandus (Smith, 1858), Gnamptogenys bruchi (Santschi, 1922) and Linepithema anathema Wild, 2007 was recorded for the first time in the state of Rio Grande do Sul, since they were not mentioned in the catalogs of Kempf (1972) and Brandão, (1991) nor in any of the state inventories performed so far.

According to Lattke (2003), species of the genus Gnamptogenys Roger, 1863 are commonly found in humid forests, nesting in decaying wood, soil or leaf litter. They are generalist predators, but some may specialize as predators of other ants, beetles and millipedes (Lattke 1990; Brown 1992). The species in the Americas were recently reviewed by Lattke et al. (2007), who recorded the occurrence of G. bruchi only in Argentina. However, its presence in Brazil has already been noted elsewhere (Bolton et al. 2006).

Very little is known about the species Linepithema anathema, recently described by Wild (2007b). However, the presence of L. micans (Forel, 1908) should be emphasized, since this species was present in all farms and treatments, with the exception of rows on Fazenda Malafai. This species was considered by Sacchett et al. (2009) as one of the main dispersers of the mealy bug popularly known as land-pearl [Eurhizococcus brasiliensis (Hempel, 1922)] in the vineyards of the city of Bento Gonçalves, in the Rio Grande do Sul Serra Gaúcha mountain range.

The species richness in this inventory was high when compared to other studies carried out in other localities in the state of Rio Grande do Sul, inserted into the Atlantic Forest biome (e.g. Fonseca and Diehl 2004; Schimidt and Diehl 2008; Albuequerque and Diehl 2009). The low richness found in these studies is probably due to differences in methodology and sampling effort, as well as to the fact that a few of these studies were carried out in altered environments which are not representative of the local natural environments. For example, Sacchett e Diehl (2004), in a study carried out with a sampling effort similar to the one used in the current study, found greater richness, collecting 62 species in protected natural areas of the restinga forest in Itapuã State Park.

Thus, it is likely that the native areas of the Atlantic Forest biome in the state have a greater species richness when compared to areas located in the Campanha region, since these are generally made up of forests which tend to offer better conditions for the establishment of ant colonies. More heterogeneous environments provide greater amount of available resources for harboring a higher diversity of species, offering greater carrying capacity, with wider availability of refuge, foraging and feeding sites, and less competitive interaction between species (Morais and Benson 1988; Hölldobler and Wilson, 1990; Folgarait 1998; Ribas et al. 2003).

Therefore, in the present study, the list of species obtained can be considered a first step towards understanding the ant fauna in grassland environments and vineyards in the region of Campanha, providing important information for future studies, as well as management of the local agroecosystems and conservation plans of natural areas. We hope that further surveys of the ant fauna would be conducted in other physiognomies and agroecosystems in the region of the Pampa biome, contributing towards developing a more complete biodiversity database about this poorly known biome. 
TABLE 1. Epigeic myrmecofauna collected with pitfall traps in vineyards (R - row; $\mathrm{S}$ - space between rows) and adjacent grassland sites (G) in the region of Campanha in the state of Rio Grande do Sul. Key: * New record for the State of Rio Grande do Sul; ** new record for Brazil.

\begin{tabular}{|c|c|c|c|c|c|c|c|c|c|}
\hline \multirow{2}{*}{ SPECIES } & \multicolumn{3}{|c|}{ MALAFAI } & \multicolumn{3}{|c|}{ MIOLO } & \multicolumn{3}{|c|}{ PERUZZO } \\
\hline & G & $\mathbf{R}$ & $\mathbf{S}$ & $\mathbf{G}$ & $\mathbf{R}$ & $\mathbf{S}$ & G & $\mathbf{R}$ & $\mathbf{S}$ \\
\hline \multicolumn{10}{|l|}{ Dolichoderinae } \\
\hline \multicolumn{10}{|l|}{ Dolichoderini } \\
\hline Dorymyrmex pyramicus (Roger, 1863) & $\mathrm{x}$ & $\mathrm{x}$ & $\mathrm{x}$ & $\mathrm{x}$ & $\mathrm{x}$ & $\mathrm{x}$ & $\mathrm{x}$ & $\mathrm{x}$ & $\mathrm{x}$ \\
\hline Dorymyrmex sp.2 & & $\mathrm{x}$ & & & $\mathrm{x}$ & $\mathrm{x}$ & & $\mathrm{x}$ & \\
\hline Forelius brasiliensis (Forel, 1908) & $\mathrm{x}$ & & & $\mathrm{x}$ & & & & & \\
\hline Tapinoma sp.1 & & & & $\mathrm{x}$ & & & & & $\mathrm{x}$ \\
\hline Linepithema anathema* Wild, 2007 & & & & $\mathrm{x}$ & & & & $\mathrm{x}$ & \\
\hline Linepithema micans (Forel, 1908) & $\mathrm{x}$ & & $\mathrm{x}$ & $\mathrm{x}$ & $\mathrm{x}$ & $\mathrm{x}$ & $\mathrm{x}$ & $\mathrm{x}$ & $\mathrm{x}$ \\
\hline \multicolumn{10}{|l|}{ Ecitoninae } \\
\hline \multicolumn{10}{|l|}{ Ecitonini } \\
\hline Neivamyrmex sp.1 & $\mathrm{x}$ & & & & & & & & \\
\hline \multicolumn{10}{|l|}{ Ectatomminae } \\
\hline \multicolumn{10}{|l|}{ Ectatommini } \\
\hline Ectatomma edentatum Roger, 1863 & $\mathrm{x}$ & & & $\mathrm{x}$ & & & & & \\
\hline Gnamptogenys bruchi*(Santschi, 1922) & & & & & & & $\mathrm{x}$ & & \\
\hline \multicolumn{10}{|l|}{ Formicinae } \\
\hline \multicolumn{10}{|l|}{ Camponotini } \\
\hline Camponotus blandus*(Smith, 1858) & $\mathrm{x}$ & & & $x$ & $\mathrm{x}$ & $\mathrm{x}$ & $\mathrm{x}$ & & \\
\hline Camponotus koseritzi Emery, 1888 & & & & $\mathrm{x}$ & & & & & \\
\hline Camponotus punctulatus Mayr, 1868 & $\mathrm{x}$ & $\mathrm{x}$ & $\mathrm{x}$ & $x$ & $\mathrm{x}$ & $\mathrm{x}$ & $\mathrm{x}$ & & \\
\hline Camponotus renggeri Emery, 1894 & $\mathrm{x}$ & & & & & & & & \\
\hline Camponotus pr. germaini & $\mathrm{x}$ & & $\mathrm{x}$ & $\mathrm{x}$ & $\mathrm{x}$ & $\mathrm{x}$ & $\mathrm{x}$ & $\mathrm{x}$ & \\
\hline \multicolumn{10}{|l|}{ Plagiolepidini } \\
\hline Brachymyrmex patagonicus Mayr, 1868 & $\mathrm{x}$ & $\mathrm{x}$ & $\mathrm{x}$ & $\mathrm{x}$ & $\mathrm{x}$ & $\mathrm{x}$ & $\mathrm{x}$ & $\mathrm{x}$ & $\mathrm{x}$ \\
\hline Brachymyrmex pr. pilipes & & & & $\mathrm{x}$ & & & & & \\
\hline Brachymyrmex sp.4 & $\mathrm{x}$ & $\mathrm{x}$ & $x$ & $x$ & $\mathrm{x}$ & $\mathrm{x}$ & $\mathrm{x}$ & $\mathrm{x}$ & $\mathrm{x}$ \\
\hline Brachymyrmex sp.12 & $\mathrm{x}$ & & $\mathrm{x}$ & $\mathrm{x}$ & $\mathrm{x}$ & & & & \\
\hline Myrmelachista gallicola Mayr, 1887 & & & & & $\mathrm{x}$ & & $\mathrm{x}$ & & \\
\hline Nylanderia fulva (Mayr, 1862) & $\mathrm{x}$ & & & $\mathrm{x}$ & $\mathrm{x}$ & $\mathrm{x}$ & $\mathrm{x}$ & & \\
\hline \multicolumn{10}{|l|}{ Myrmicinae } \\
\hline Attini & & & & & & & & & \\
\hline Acromyrmex ambiguus (Emery, 1888) & & $\mathrm{x}$ & & $\mathrm{x}$ & $\mathrm{x}$ & $\mathrm{x}$ & $\mathrm{x}$ & & \\
\hline Acromyrmex balzani (Emery, 1890) & & & & $\mathrm{x}$ & & & & & \\
\hline Acromyrmex crassispinus (Forel, 1909) & $\mathrm{x}$ & & & & $\mathrm{x}$ & $\mathrm{x}$ & $\mathrm{x}$ & & \\
\hline Acromyrmex heyeri (Forel, 1899) & $\mathrm{x}$ & & & $\mathrm{x}$ & $\mathrm{x}$ & $\mathrm{x}$ & $\mathrm{x}$ & & $\mathrm{x}$ \\
\hline Acromyrmex lobicornis (Emery, 1888) & & & & & & $\mathrm{x}$ & & & \\
\hline Acromyrmex lundi (Guérin-Méneville, 1838) & $\mathrm{x}$ & $\mathrm{x}$ & $\mathrm{x}$ & & $\mathrm{x}$ & $\mathrm{x}$ & $\mathrm{x}$ & $\mathrm{x}$ & $\mathrm{x}$ \\
\hline Acromyrmex striatus (Roger, 1863) & & & & $\mathrm{x}$ & & & $\mathrm{x}$ & & \\
\hline Cyphomyrmex rimosus (Spinola, 1851) & $\mathrm{x}$ & $\mathrm{x}$ & $\mathrm{x}$ & $x$ & $x$ & $\mathrm{x}$ & $\mathrm{x}$ & & \\
\hline Trachymyrmex holmgreni Wheeler (1925) & $\mathrm{x}$ & $\mathrm{x}$ & $\mathrm{x}$ & $\mathrm{x}$ & $\mathrm{x}$ & $\mathrm{x}$ & $\mathrm{x}$ & $\mathrm{x}$ & \\
\hline Trachymyrmex sp.1 & $\mathrm{x}$ & & & $\mathrm{x}$ & & & & & \\
\hline Blepharidattini & & & & & & & & & \\
\hline Wasmannia auropunctata (Roger, 1863) & $\mathrm{x}$ & $\mathrm{x}$ & $\mathrm{x}$ & $\mathrm{x}$ & $\mathrm{x}$ & $\mathrm{x}$ & $\mathrm{x}$ & $\mathrm{x}$ & $\mathrm{x}$ \\
\hline Wasmannia williamsoni Kusnezov, 1952 & $\mathrm{x}$ & & & $\mathrm{x}$ & & & & & \\
\hline Crematogastrini & & & & & & & & & \\
\hline Crematogaster bruchi ${ }^{* *}$ Forel, 1912 & & & & $\mathrm{x}$ & $\mathrm{x}$ & $\mathrm{x}$ & $\mathrm{x}$ & & $\mathrm{x}$ \\
\hline Crematogaster quadriformis Roger, 1863 & $\mathrm{x}$ & $\mathrm{x}$ & $\mathrm{x}$ & $\mathrm{x}$ & $\mathrm{x}$ & $\mathrm{x}$ & $\mathrm{x}$ & $\mathrm{x}$ & $\mathrm{x}$ \\
\hline Crematogaster sp.3 & $\mathrm{x}$ & $\mathrm{x}$ & & $\mathrm{x}$ & & & $\mathrm{x}$ & $\mathrm{x}$ & $\mathrm{x}$ \\
\hline Dacetini & & & & & & & & & \\
\hline Strumigenys louisianae Roger, 1863 & & $\mathrm{x}$ & $\mathrm{x}$ & & & & $\mathrm{x}$ & & \\
\hline Myrmicini & & & & & & & & & \\
\hline Pogonomyrmex coarctatus Mayr, 1868 & & & & $\mathrm{x}$ & & & & & \\
\hline Pogonomyrmex naegelii Emery, 1878 & $\mathrm{x}$ & & & $\mathrm{x}$ & $\mathrm{x}$ & $\mathrm{x}$ & $\mathrm{x}$ & & \\
\hline Pheidolini & & & & & & & & & \\
\hline Pheidole aberrans Mayr, 1868 & $\mathrm{x}$ & $\mathrm{x}$ & $\mathrm{x}$ & $\mathrm{x}$ & $\mathrm{x}$ & $\mathrm{x}$ & $\mathrm{x}$ & $\mathrm{x}$ & $\mathrm{x}$ \\
\hline Pheidole cavifrons Emery, 1906 & & & $\mathrm{x}$ & $x$ & & & & & \\
\hline Pheidole humeridens Wilson, 2003 & $\mathrm{x}$ & $\mathrm{x}$ & $\mathrm{x}$ & $\mathrm{x}$ & $\mathrm{x}$ & $\mathrm{x}$ & $\mathrm{x}$ & $\mathrm{x}$ & $\mathrm{x}$ \\
\hline Pheidole nubila Emery, 1906 & $\mathrm{x}$ & $\mathrm{x}$ & $\mathrm{x}$ & $\mathrm{x}$ & $\mathrm{x}$ & $\mathrm{x}$ & $\mathrm{x}$ & $\mathrm{x}$ & $\mathrm{x}$ \\
\hline
\end{tabular}


TABLE 1. CONTINUED.

\begin{tabular}{|c|c|c|c|c|c|c|c|c|c|}
\hline \multirow{2}{*}{ SPECIES } & \multicolumn{3}{|c|}{ MALAFAI } & \multicolumn{3}{|c|}{ MIOLO } & \multicolumn{3}{|c|}{ PERUZZO } \\
\hline & G & $\mathbf{R}$ & $\mathbf{S}$ & G & $\mathbf{R}$ & $\mathbf{S}$ & G & $\mathbf{R}$ & $\mathbf{S}$ \\
\hline Pheidole obscurithorax Naves, 1985 & $\mathrm{x}$ & & & $\mathrm{x}$ & & & $\mathrm{x}$ & & \\
\hline Pheidole obtusopilosa Mayr, 1887 & $\mathrm{x}$ & $\mathrm{x}$ & $\mathrm{x}$ & $\mathrm{x}$ & $\mathrm{x}$ & $\mathrm{x}$ & $\mathrm{x}$ & $\mathrm{x}$ & $\mathrm{x}$ \\
\hline Pheidole spininods Mayr, 1887 & $\mathrm{x}$ & $\mathrm{x}$ & $\mathrm{x}$ & $\mathrm{x}$ & $\mathrm{x}$ & $x$ & $\mathrm{x}$ & $\mathrm{x}$ & $\mathrm{x}$ \\
\hline Pheidole subarmata Mayr, 1884 & & & & $\mathrm{x}$ & & & & $\mathrm{x}$ & \\
\hline Pheidole sp.1 & $\mathrm{x}$ & $\mathrm{x}$ & $\mathrm{x}$ & & & & $\mathrm{x}$ & $\mathrm{x}$ & $\mathrm{x}$ \\
\hline Pheidole sp.2 & & & & $\mathrm{x}$ & $\mathrm{x}$ & $\mathrm{x}$ & & & \\
\hline Pheidole sp.3 & $\mathrm{x}$ & $\mathrm{x}$ & $\mathrm{x}$ & $\mathrm{x}$ & $\mathrm{x}$ & $\mathrm{x}$ & $\mathrm{x}$ & $\mathrm{x}$ & $\mathrm{x}$ \\
\hline Pheidole sp.4 & $\mathrm{x}$ & $\mathrm{x}$ & $\mathrm{x}$ & $\mathrm{x}$ & $\mathrm{x}$ & $\mathrm{x}$ & $\mathrm{x}$ & $\mathrm{x}$ & $\mathrm{x}$ \\
\hline \multicolumn{10}{|l|}{ Solenopsidini } \\
\hline Solenopsis sp.1 & $\mathrm{x}$ & $\mathrm{x}$ & $\mathrm{x}$ & $\mathrm{x}$ & $\mathrm{x}$ & $\mathrm{x}$ & $\mathrm{x}$ & $\mathrm{x}$ & $\mathrm{x}$ \\
\hline Solenopsis sp.2 & $\mathrm{x}$ & & $\mathrm{x}$ & $\mathrm{x}$ & $\mathrm{x}$ & $\mathrm{x}$ & $\mathrm{x}$ & $\mathrm{x}$ & \\
\hline Solenopsis sp.5 & $\mathrm{x}$ & & $\mathrm{x}$ & $\mathrm{x}$ & $\mathrm{x}$ & $x$ & $\mathrm{x}$ & $\mathrm{x}$ & $\mathrm{x}$ \\
\hline Solenopsis sp.7 & $\mathrm{x}$ & $\mathrm{x}$ & $\mathrm{x}$ & $\mathrm{x}$ & $\mathrm{x}$ & $\mathrm{x}$ & $\mathrm{x}$ & & $\mathrm{x}$ \\
\hline Solenopsis sp.8 & & & & $\mathrm{x}$ & & $\mathrm{x}$ & & & \\
\hline Solenopsis sp.9 & $\mathrm{x}$ & & & $\mathrm{x}$ & & & & & \\
\hline Solenopsis sp.10 & $\mathrm{x}$ & & & & $\mathrm{x}$ & & & $\mathrm{x}$ & \\
\hline Solenopsis sp.12 & & & $\mathrm{x}$ & & & & & & \\
\hline Solenopsis sp.13 & & & & & $\mathrm{x}$ & & & & \\
\hline Solenopsis sp.14 & & & & & & & $\mathrm{x}$ & & \\
\hline Solenopsis sp.15 & & & & & $\mathrm{x}$ & & & & \\
\hline \multicolumn{10}{|l|}{ Ponerinae } \\
\hline \multicolumn{10}{|l|}{ Ponerini } \\
\hline Anochetus (gr. inermis) sp.1 & & & & & & $\mathrm{x}$ & & $\mathrm{x}$ & $\mathrm{x}$ \\
\hline Hypoponera sp.1 & & & & $\mathrm{x}$ & & $x$ & & & \\
\hline Hypoponera sp.2 & & & $\mathrm{x}$ & & & & & & \\
\hline Hyроропеra sp.3 & & & & $\mathrm{x}$ & & & $\mathrm{x}$ & & \\
\hline Hypoponera sp.4 & & & & & $\mathrm{x}$ & & $\mathrm{x}$ & & \\
\hline Hyроропеra sp.5 & & & & & $\mathrm{x}$ & $\mathrm{x}$ & & & \\
\hline Hуроропеra sp.6 & & & & $\mathrm{x}$ & & & & & \\
\hline Hypoponera sp.7 & & & & & & & $\mathrm{x}$ & & \\
\hline Pachycondyla bucki (Borgmeier, 1927) & & & & & & & $\mathrm{x}$ & & \\
\hline Pachycondyla striata Smith, 1858 & $\mathrm{x}$ & & & $\mathrm{x}$ & $\mathrm{x}$ & $\mathrm{x}$ & & & \\
\hline \multicolumn{10}{|l|}{ Pseudomyrmecinae } \\
\hline \multicolumn{10}{|l|}{ Pseudomyrmecini } \\
\hline Pseudomyrmex termitarius (Smith, 1855) & & & & & $\mathrm{x}$ & & & $\mathrm{x}$ & $\mathrm{x}$ \\
\hline TOTAL NUMBER OF SPECIES & 40 & 23 & 28 & 50 & 40 & 37 & 41 & 27 & 24 \\
\hline
\end{tabular}

ACKNOWLEDGMents: The authors thank Helter Lopes, Marcieli Hobuss, Melina Gomes, Ricardo Dessbesell and Tania Bayer for their assistance in the collections. We thank the farms and their employees for their support and provision of study areas. We also thank CNPq for granting a scholarship to the first author. RMF received support from the Fundação de Amparo à Pesquisa do Estado de São Paulo (Proc. 11/24160-1).

\section{Literature Cited}

Agosti, D. and N.F. Johnson. 2003. La nueva taxonomía de hormigas, p: 45-48. In F. Fernández (ed.). Introducción a las hormigas de la región Neotropical. Bogotá: Instituto de Investigación de Recursos Biológicos Alexander Von Humboldt. 398 p.

Agosti, D. and N.F. Johnson. 2012. World Wide Web electronic publication. Electronic Database accessible at http//www.antbase.org. Captured on 21 January 2012.

Albuquerque, E.Z.D. and E. Diehl. 2009. Análise faunística das formigas epígeas (Hymenoptera, Formicidae) em campo nativo no Planalto das Araucárias, Rio Grande do Sul. Revista Brasileira de Entomologia 53(3): 398-403.

Alonso, L.E. and D. Agosti. 2000. Biodiversity studies, monitoring, and ants: an overview, p: 1-8. In D. Agosti, J.D. Majer, L.E. Alonso and T.R. Schultz (ed). Ants: Standard methods for measuring and monitoring biodiversity. Washington, USA: Smithsonian Institution Press. 280 p.

Andrade, T., G.D.V. Marques and K. Del-Claro. 2007. Diversity of ground dwelling ants in Cerrado: an analysis of temporal variations and distinctive physiognomies of vegetation (Hymenoptera:Formicidae). Sociobiology 50 (1): 121-134.
Bolton, B., G. Alpert, P.S. Ward and P. Naskrecki. 2006. Bolton's Catalogue of ants of the world. Cambridge, USA: Harvard University Press.

Brandão, C.R.F. 1991. Adendos ao catálogo abreviado das formigas da região neotropical (Hymenoptera: Formicidae). Revista Brasileira de Agroecologia 35(2): 319-412.

Brown, W.L.J. 1992. Two new species of Gnamptogenys, and an account of millipede predation by one of them. Psyche 99: 275-289.

Corrêa, M.M., W.D. Fernandes and I.R. Leal. 2006. Diversidade de formigas epigéicas (Hymenoptera: Formicidae) em capões do Pantanal Sul Matogrossense: relações entre riqueza de espécies e complexidade estrutural da área. Neotropical Entomology 35(6): 724-730.

Delabie, J.H.C., B.L. Fisher, J.D. Majer and W. Wright. 2000. Sampling effort and choice of methods, p: 145-154. In J.D. Majer, D. Agosti, L.E. Alonso and T.R. Schultz (ed.). Ants: standard methods for measuring and monitoring biodiversity. XIX. Washington: Smithsonian Institution Press. $280 \mathrm{p}$.

Delabie, J.H.C. and H.G. Fowler. 1995. Soil and litter cryptic ant assemblages of Bahia cocoa plantations. Pedobiologia 39(1): 423-433.

Dias, N.S., R. Zanetti, M.S. Santos, J. Louzada and J.H.C. 2008. Interação de fragmentos florestais com agroecossistemas adjacentes de café e pastagem: respostas das comunidades de formigas (Hymenoptera, Formicidae). Iheringia Série Zoologia 98(1): 136-142.

Folgarait, P.J. 1998. Ant biodiversity and its relationship to ecosystem functioning: a review. Biodiversity and Conservation 7: 1221-1244.

Fonseca, R.C. and E. Diehl. 2004. Riqueza de formigas (Hymenoptera, Formicidae) epigéicas em povoamentos de Eucalyptus spp. (Myrtaceae) de diferentes idades no Rio Grande do Sul, Brasil. Revista Brasileira de Entomologia 48(1): 95-100. 
Fortes, A.B. 1959. Geografia física do Rio Grande do Sul. Porto Alegre: Editora Globo. 393 p.

Fowler, H.G. 1993. Relative representation of Pheidole (Hymenoptera: Formicidae) in local ground ant assemblages of the Americas. Anales de Biología 9: 29-37.

Fowler, H.G., L.C. Forti, C.R.F. Brandão, J.H.C. Delabie and H.L. Vasconcelos. 1991. Ecologia nutricional de formigas, p. 131-223. In A.R. Panizzi and J.R.P. Parra (ed.). Ecologia nutricional de insetos e suas aplicações no manejo de pragas. São Paulo: Editora Manole. 359 p.

Garcia, M.A. 2001. Ecologia aplicada a agroecossistemas como base para a sustentabilidade. Informe Agropecuário 22(213): 30-38.

Gomes, J.P., L. Iannuzzi and I.R. Leal. 2010. Resposta da comunidade de formigas aos atributos dos fragmentos e da vegetação em uma paisagem da Floresta Atlântica Nordestina. Neotropical Entomology 39(6): 898-905.

Gonçalves, C. 1961. O Gênero Acromyrmex no Brasil. Studia Entomologica 4: 113-180.

Gonçalves, C.R. and A.M. Nunes. 1984. Formigas das praias e restingas do Brasil; p. 373-378.In L.D. Lacerda, D.S.D. Araújo, R. Cerqueira and B. Tureq (ed.). Restingas: origem, estrutura, processos. Niterói: CEUFF.

Hölldobler, B. and E.O. Wilson. 1990. The Ants. Belknap (Harvard University Press), Cambridge. Science 248(4957): 897-898.

IBGE. 2004. Mapa de biomas e de vegetação. Electronic Database accessible at http://www.ibge.gov.br/home/presidencia/noticias/ noticia_visualiza.php?id_noticia=169. Captured on 23 january 2012.

Kempf, W.W. 1965. A revision of the neotropical fungus-growing ants of the Genus Cyphomyrmex Mayr. Part II: group of rimosus (Spinola) (Hym. Formicidae). Studia Entomologica 8: 163-200.

Kempf, W.W. 1972. Catálogo abreviado das formigas (Hymenoptera:Formicidae) da região Neotropical. Studia Entomologica 15(1-4): 3-343.

Köppen, W. 1936. Das geographisca System der Klimate. In W. Köppen and G. Geiger (ed.). Handbuch der Klimatologie. Gebr, Borntraeger, p. $1-44$.

Lach, L., C.L. Parr and K.L. Abbott. 2010. Ant ecology. Oxford :Oxford University Press.

Lapolla, J., S.G. Brady and S.O. Shattuck. 2010. Phylogeny and taxonomy of the Prenolepis genus-group of ants (Hymenoptera: Formicidae). Systematic Entomology 35:118-131.

Lattke, J.E. 1990. Revisión del género Gnamptogenys Mayr para Venezuela. Acta Terramaris 2: 1-47.

Lattke, J.E. 2003. Subfamilia Ponerinae, p: 261-276. In F. Fernández (ed.). Introducción a las hormigas de la región neotropical. Bogotá, Colômbia: Instituto de Investigación de Recursos Biológicos Alexander Von Humbolt. 398 p.

Lattke, J.E., F. Fernández and E.E. Palacio. 2007. Identification of the species of Gnamptogenys Roger in the Americas. Memoirs of the American Entomological Institute 80: 254-270.

Loeck, A.E. and D.D. Grützmacher. 2001. Ocorrência de formigas cortadeiras nas principais regiões agropecuárias do estado do Rio Grande do Sul. Pelotas, Brasil: Editora Universitária/Ufpel. 147 p.

Loeck, A.E., D.D. Grützmacher and S.M. Coimbra. 2003. Ocorrência de formigas cortadeiras do gênero Acromyrmex nas principais regiões agropecuárias do estado do Rio Grande do Sul. Revista Brasileira de Agroecologia 9(2): 129-133.

Longino, J.T. and F. Fernández. 2007. Taxonomic review of the genus Wasmannia. In R.R. Snelling, B.L. Fisher and P.S. Ward (ed.). Advances in ant systematics (Hymenoptera: Formicidae): homage to E. O. Wilson - 50 years of contributions. Gainesville, USA: Memoirs of the American Entomological Institute. 280p.

Lopes, D.T., J. Lopes, I.C. do Nascimento and J.H.C. Delabie. 2010. Diversidade de formigas epigéicas (Hymenoptera, Formicidae) em três ambientes no Parque Estadual Mata dos Godoy, Londrina, Paraná. Iheringia Série Zoologia 100(1): 84-90.

Majer, J.D. 1983. Ants: bio-indicators of minesite rehabilitation, land-use, and land conservation. Environmental Management 7: 375-383.

Marchiori, J.N.C. 2004. Fitogeografia do Rio Grande do Sul: campos sulinos. $110 \mathrm{p}$.

Marinho, C.G.S., R. Zanetti, J.H.C. Delabie, M.N. Schlindwein and L.S Ramos. 2002. Diversidade de formigas (Hymenoptera: Formicidae) da serapilheira em eucaliptais (Myrtaceae) e área de cerrado de Minas Gerais. Neotropical Entomology 31(2): 187-195.

Morais, H.C. and W.W. Benson. 1988. Recolonização de vegetação de cerrado após queimada, por formigas arborícolas. Revista Brasileira de Biologia 48: 459-466.

Overbeck, G.E., S.C. Müller, A. Fidelis, J. Pfadenhaver, V.P. Pillar, C.C. Blanco, I.L. Boldrini, R. Both and E.D. Forneck. 2009. Os campos sulinos: um bioma negligenciado; p. 26-41. In V.P. Pillar, S.C. Müller, Z.M.S. Castilhos and A.V.A. Jaques (ed.). Campos Sulinos - conservação e uso sustentável da biodiversidade. Brasília: Ministério do Meio Ambiente. 403p.
Palacio, E.E. and F. Fernández. 2003. Claves para las subfamilias y géneros, p: 233-260. In F. Fernández (ed.). Introducción a las hormigas de la región neotropical. Bogotá, Colômbia: Instituto de Investigación de Recursos Biológicos Alexander Von Humbolt. 398 p.

Peel, M.C., B.L. Finlayson and T.A. McMahon. 2007. Updated world map of the Köppen-Geiger climate classification. Hydrology and Earth System Sciences 11: 1633-1644.

Pillar, V.P., S.C. Müller, Z.M.S. Castilhos and A.V.A. Jaques. 2009. Campos Sulinos - conservação e uso sustentável da biodiversidade. Brasília: Ministério do Meio Ambiente. 403p.

Prado, A.P. 1980. Importância prática da taxonomia (ou o papel da taxonomia para a Entomologia Aplicada). Revista Brasileira de Entomologia 24(2): 165-167.

Queiroz, J.M., F.S. Almeida and M.P.S. Pereira. 2006. Conservação da biodiversidade e o papel das formigas (Hymenoptera: Formicidae) em agroecossistemas. Floresta e Ambiente 13(2): 37-45.

Ramos, L.S., R. Zanetti, J.H.C. Delabie, S. Lacau, M.F.S. dos Santos, I.C. do Nascimento and C.G.S. Marinho. 2003. Comunidades de formigas (Hymenoptera: Formicidae) de serapilheira em áreas de cerrado "stricto sensu" em Minas Gerais. Lundiana 4(2): 95-102.

Ribas, C.R.,J.H. Schoereder, M. Pic and S.M. Soares. 2003.Tree heterogeneity, resource availability, and larger scale process regulating arboreal ant species richness. Austral Ecology 28: 305-314.

Rosumek, F.B., M.A. Ulysséa, B.C. Lopes, J. Steiner and A. Zillikens. 2008. Formigas de solo e de bromélias em uma área de Mata Atlântica, Ilha de Santa Catarina, sul do Brasil: Levantamento de espécies e novos registros. Biotemas 21(4): 81-89.

Sacchett, F., M. Botton and E. Diehl. 2009. Ant species associated with the dispersal of Eurhizococcus brasiliensis (Hempel in Wille) (Hemiptera: Margarodidae) in vineyards of the Serra Gaúcha, Rio Grande do Sul, Brazil. Sociobiology 54(3): 943-954.

Sacchett, F. and E. Diehl. 2004. Comunidades de formigas de solo no morro da Grota, Parque Estadual de Itapuã, RS. Acta Biológica Leopoldensia 26: 79-92.

Schmidt, F.A. and E. Diehl. 2008. What is the effect of soil use on ant communities? Neotropical Entomology 37(4): 381-388.

Silva, R.R., C.R.F. Brandão and C.B. Urbani. 1999. Formigas (Hymenoptera: Formicidae) como indicadores da qualidade ambiental e da biodiversidade de outros invertebrados terrestres. Biotemas 12(2): 55-73.

Silvestre, R.C., C.R.F. Brandão and R.R. Silva. 2003. Grupos funcionales de hormigas: el caso de los gremios del Cerrado, p.113-148. In F. Fernández (ed.). Introducción a las hormigas de la región neotropical. Bogotá, Colômbia: Instituto de Investigación de Recursos Biológicos Alexander Von Humbolt. 398 p.

Soares, S.A., W.F. Antonialli-Junior and S.E. Lima-Junior. 2010. Diversidade de formigas epigéicas (Hymenoptera, Formicidae) em dois ambientes no Centro-Oeste do Brasil. Revista Brasileira de Entomologia 54(1): 76-81.

Vittar, F. 2008. Hormigas (Hymenoptera: Formicidae) de la Mesopotamia Argentina. Insugeo 17(2): 447-466.

Vittar, F. and F.C. Cuezzo. 2008. Hormigas (Hymenoptera: Formicidae) de la provincia de Santa Fe, Argentina. Revista de la Sociedad Entomológica Argentina 67(1-2): 175-178.

Watkins, J.F. 1976. The identification and distribution of new world army ants (Dorylinae: Formicidae). Texas, USA: The Markham Press Fund of Baylor University Press. Baylor University.102p.

Wild, A.L. 2007a. A catalogue of the ants of Paraguay (Hymenoptera: Formicidae). Zootaxa 1622:1-55.

Wild, A.L. 2007b. Taxonomic revision of the ant genus Linepithema (Hymenoptera:Formicidae). Los Angeles, USA: University of California Publications in Entomology. 162p.

Wilson, E.O. 1997. A situação atual da diversidade biológica, p. 3-24. In E.O. Wilson and M.P. Frances (ed.). Biodiversidade. Rio de Janeiro: Nova Fronteira. 657p.

Wilson, E.0. 2003. Pheidole in the new world: a dominant, hyperdiverse ant gemus. Cambridge: Harvard University Press. 794 p.

RECEIVED: June 2012

ACCEPTED: October 2012

Published ONLINE: December 2012

EDITORIAL RESPONSIBILITY: Ricardo Solar 